\title{
A STUDY OF THE TRITERPENES OF EUPHORBIA JAXARTICA
}

M. A. Azimov and Z. N. Nazirov

Khimiya Prirodnykh Soedinenii, Vol. 5, No. 6, p. 599, 1969

UDC $547.913: 618.3$

We have previously reported the isolation of carbohydrates, alcohols, and acids from E. lamprocarpa Benth. [1].

In this paper we give the results of a study of the triterpene compounds from E. jaxartica Prokh.

The conminuted raw material was extracted with chloroform. The chloroform was distilled off and the residue was dissolved in acetone. The acetone-soluble fraction was treated with petroleum ether and chromatographed on alumina. Elution was then carried out successively with petroleum ether, benzene, acetone, and methanol.

The benzene eluate deposited crystals with $\mathrm{mp} 137-138^{\circ} \mathrm{C},[\alpha]_{\mathrm{D}}^{20}-36^{\circ}$ (chloroform), with the composition $\mathrm{C}_{29} \mathrm{H}_{50} \mathrm{O}$. The substance formed an $\mathrm{O}$-acetyl derivative with $\mathrm{mp} 128-129^{\circ} \mathrm{C}$, and an O-benzoyl derivative with $\mathrm{mp} 145-146^{\circ} \mathrm{C}$. By a comparison of the IR spectra and a mixed-melting-point determination, the substance was identified as $\beta$-sitosterol [2].

From the first ethereal fraction, after the distillation of the solvent, crystals were obtained with $\mathrm{mp} 113-114^{\circ} \mathrm{C}$, with the composition $\mathrm{C}_{30} \mathrm{H}_{50} \mathrm{O},[\alpha]_{\mathrm{D}}^{20}+29.2^{\circ}$, forming an O-acetyl derivative with $\mathrm{mp} 104-105^{\circ} \mathrm{C}$ and an $\mathrm{O}-$ benzoyl derivative with $\mathrm{mp} 135-137^{\circ} \mathrm{C}$.

The physicochemical properties of this compound are similar to those of the euphol which has been isolated previously from plants of the genus Euphorbia [3]. identical.

A mixture with an authentic sample of euphol gave no depression of the melting point and their IR spectra were

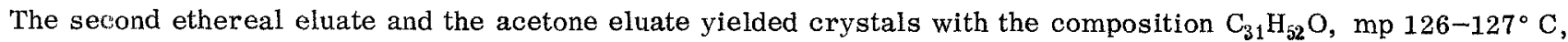
$[\alpha]_{\mathrm{D}}^{20} \pm 0^{\circ}$. The substance formed an $\mathrm{O}$-acetyl derivative with $\mathrm{mp} 126^{\circ} \mathrm{C}$. The properties of this substance were identical with those of euphorbol, also isolated from spurge [4]. A mixture of the substance that we had obtained with euphorbol gave no depression of the melting point, and their IR spectra were identical.

\section{RE FERENCES}

1. M. A. Azimov and Z. N. Nazirov, KhPS [Chemistry of Natural Compounds], 5, 432, 1969.

2. W. Karrer, Konstitution und Vorkommen der Organischen Pflanzenstoffe, 855, 1958.

3. A. D. McDonald, F. L. Warren, and J. M. Williams, J. Chem. Soc., 155, 1949.

4. K. H. Baner and P. Schenkel, Arch. Pharm., 633, 1928.

25 June 1969

Tashkent Phermaceutical Institute 